Bradleya 30/2012

pages $3-8$

\title{
Aloe huntleyana, a new species from the Baynes Mountains, Namibia
}

\author{
Ernst J. van Jaarsveld ${ }^{1}$ and Wessel Swanepoe/ \\ ${ }^{1}$ Kirstenbosch National Botanical Garden, South African National Biodiversity Institute, Private Bag X7, 7735 \\ Claremont, Cape Town, South Africa (email: E.vanjaarsveld@ sanbi.org.za). Associate Researcher, Dept. of \\ Biodiversity \& Conservation Biology, University of the Western Cape, Private Bag X17, Bellville 7535, \\ South Africa. \\ 2 H.G.W.J. Schweickerdt Herbarium, Dept. of Plant Science, University of Pretoria, Pretoria 0002, South Africa. \\ Postal address: P.O. Box 21168, Windhoek, Namibia (email: Wessel@ kaokosafari.com).
}

\begin{abstract}
Summary: Aloe huntleyana Van Jaarsv. \& Swanepoel is named from the Kaokoveld. It belongs to a group of five closely related species from southern Angola, but immediately distinguished by its leaves which remain persistent along the stems, its horizontally spreading to drooping inflorescence of relatively short subdense racemes, of which the flowers are subsecundly arranged. The flowers when fully open are spreading nutant and not pendent.
\end{abstract}

Zusammenfassung: Aloe huntleyana Van Jaarsv. \& Swanepoel wird als neues Taxon aus dem Kaokoveld beschrieben. Sie gehört in eine Gruppe von fünf nahe miteinander verwandten Arten aus dem südlichen Angola, unterscheidet sich aber auf den ersten Blick durch die Blätter, die entlang dem Stamm ausdauernd sind, sowie durch die horizontal ausgebreiteten bis überhängenden Blütenstände mit relativ kurzen, eher dichten Rispen mit annähernd einseitswendig angeordneten Blüten. Bei voller Öffnung sind die Blüten ausgebreitet-nickend, nicht hängend.

\section{Introduction}

Aloe huntleyana was first collected on an expedition to Omavanda, northern Namibia, on July $7^{\text {th }}$ 2004 by Steven Carr and the authors on the eastern upper margin of the plateau, just below $2,000 \mathrm{~m}$ (Figures 1-2). Only a single young plant (Figure 3) was spotted growing from a rock face (Van Jaarsveld, 2008). This young plant was collected and grown on at Kirstenbosch National Botanical Garden. The plant grew rapidly, soon becoming branched, bearing spreading scandent branches. When it first came into flower it was thought to be Aloe catengiana. Several attempts to relocate $A$. catengiana at Catengue Railway Station failed. The authors were privileged to visit Angola on three occasions and collected the related species Aloe vallaris, A. palmiformis, A. gossweileri and A. scorpioides. These were all grown at Kirstenbosch, flowering annually and their behaviour studied, specimens prepared and comparisons made. One of us (E.v.J.) was also pleasantly surprised when photos of a flowering A. catengiana were received from Duke Benadom, former editor of the Cactus and Succulent Journal of America and the identity of the Omavanda plant clarified, here described as a new species.

Aloe huntleyana Van Jaarsv. \& Swanepoel spec. nov. ab Aloe vallariana Leach foliis a caulem persistentibus, inflorescentiis 1-3-ramosis, racemis subdensis e subcapitatis, $130-150 \mathrm{~mm}$ longis, floribus subsecunde dispositis $28 \mathrm{~mm}$ longis, ad anthesim patentibus sed haud pendentibus discedit.

Type: Namibia, 1713 (Swartbooisdrif): Omavanda, upper east facing sandstone cliffs. (-AA), Van Jaarsveld, Swanepoel \& Steven Carr 18805 (Wind, holo.).

Arborescent shrub, much-branched from its base, spreading to pendent, up to $0.5 \mathrm{~m}$ long and $2 \mathrm{~m}$ wide. Roots fleshy. Branches not straight, often with a slight zig-zag, leafy, $12-14 \mathrm{~mm}$ in diameter, with leaves tending to be crowded in apical rosettes of about $300-400 \mathrm{~mm}$ in diameter; internodes $15-20 \mathrm{~mm}$ long. Leaves linear-lanceolate, 160-180 × 20-30 mm, spreading, recurved in upper half, slightly falcate, greyish green but turning reddish in the dry season; upper surface flat to convex, slightly channelled during the dry season, lower surface convex, sparingly spotted in lower half, distinctly striate at the amplexicaul internodes; margin sinuate-dentate, armed with 


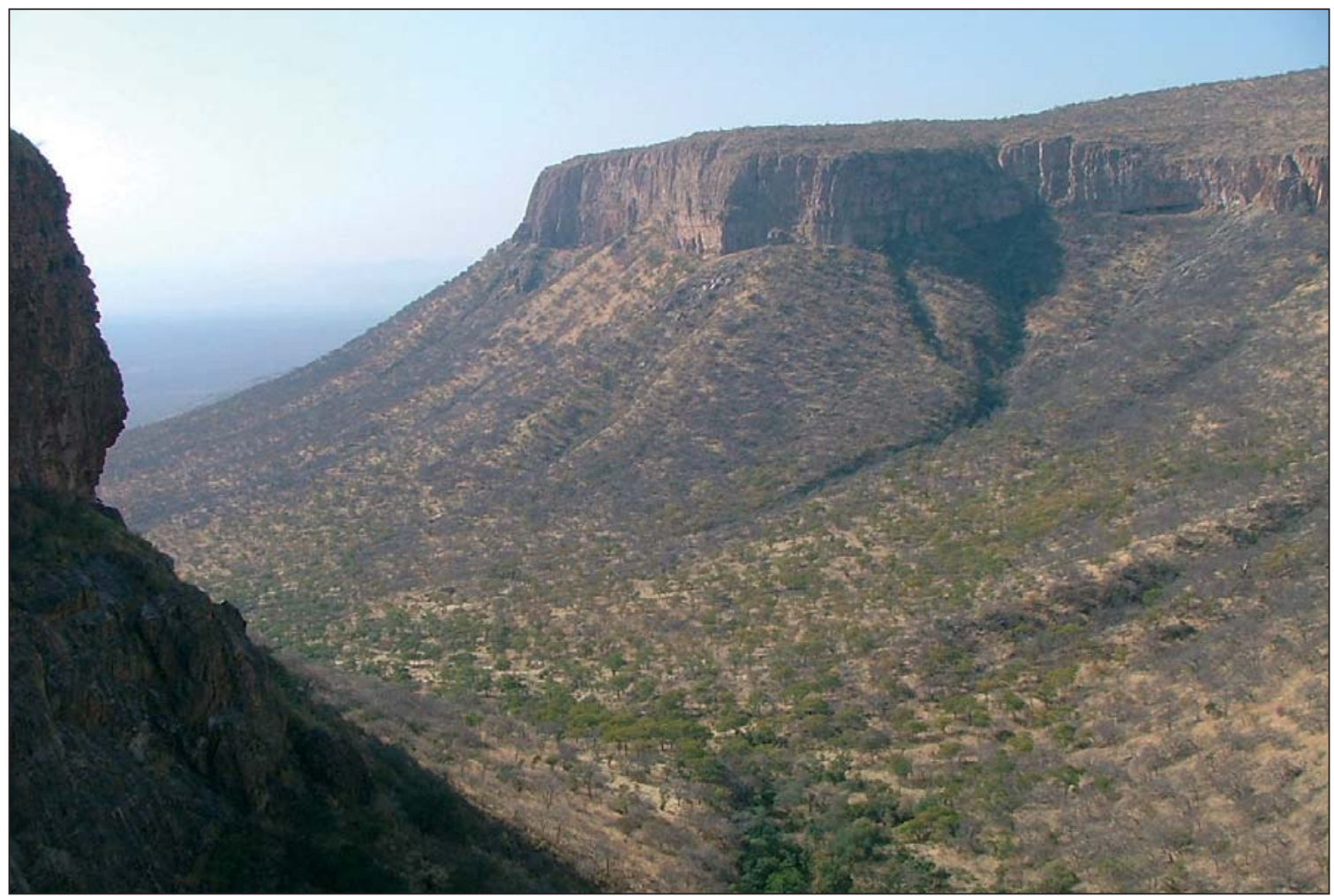

Figure 1. The Baynes Mountains at Omavanda, Namibia.

yellowish green pungent teeth $3-5 \mathrm{~mm}$ long and 8-12 mm apart; apices acuminate. Inflorescence up to 300-400 mm long, simple, or divaricate with up to 3 branches in lower half, at first pendent with apices bending up, the lowest branch distinctly arcuate ascending. Peduncle plano-convex at its base $7-10 \mathrm{~mm}$ in diameter, purplish green to green, with few sterile bracts the longest $10 \times 15 \mathrm{~mm}$.

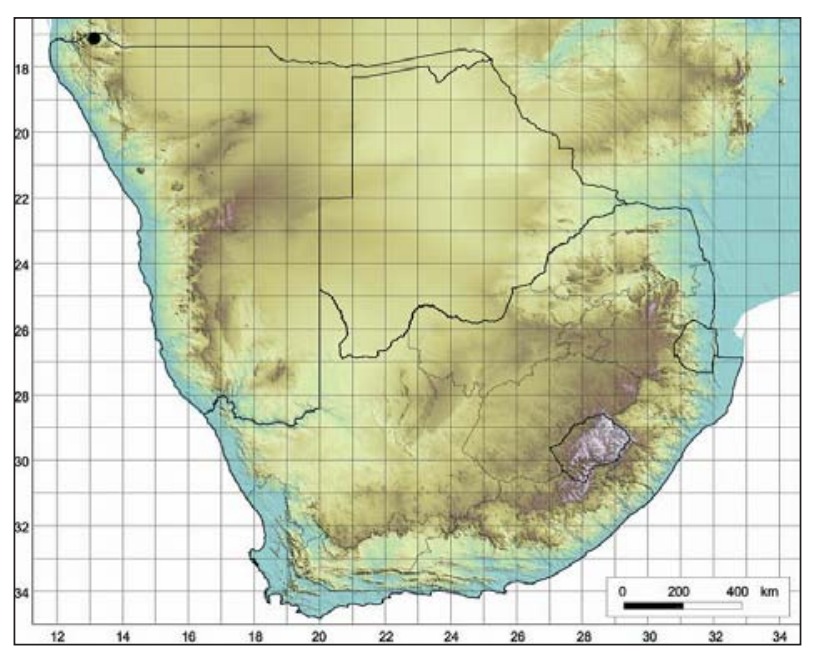

Figure 2. The distribution of A. huntleyana in northern Namibia.
Racemes conical-triangular, subdensely and subsecundly flowered, 130-150 mm long and 40$50 \mathrm{~mm}$ in diameter the lateral $80-110 \mathrm{~mm}$, the buds ascending spreading, open flowers spreading, but slightly drooping; pedicels 8-10 mm long; bracts ovate-acuminate scarious, up to $5 \times 3 \mathrm{~mm}$ becoming smaller upwards. Perianth red, becoming whitish and yellowish at the apex in open flowers, cylindrical, slightly decurved, 28-29 $\mathrm{mm}$ long; base obtuse, very shortly stipitate and $6 \mathrm{~mm}$ in diameter; outer segments free for 10 $\mathrm{mm}, 3-4 \mathrm{~mm}$ broad, inner segments $4-5 \mathrm{~mm}$ broad, apices obtuse. Anthers about $3 \mathrm{~mm}$ long, pollen reddish pink, becoming shortly exerted (about $2 \mathrm{~mm}$ ). Ovary green $5 \times 2.5 \mathrm{~mm}$. Stigma exserted to $2 \mathrm{~mm}$. Capsule and seed not seen. (Figures 3-7.)

Flowering time: mainly in autumn (April-June). Seeds dispersed by wind in winter, just before the spring rains.

\section{Discussion}

A. huntleyana grows on east-facing sandstone cliffs (Damara Sequence) on the Omavanda escarpment margin (the northeastern Baynes Mountains) at an altitude of 1,800-2,000 m (Figures 1-2). A. huntleyana grows firmly 

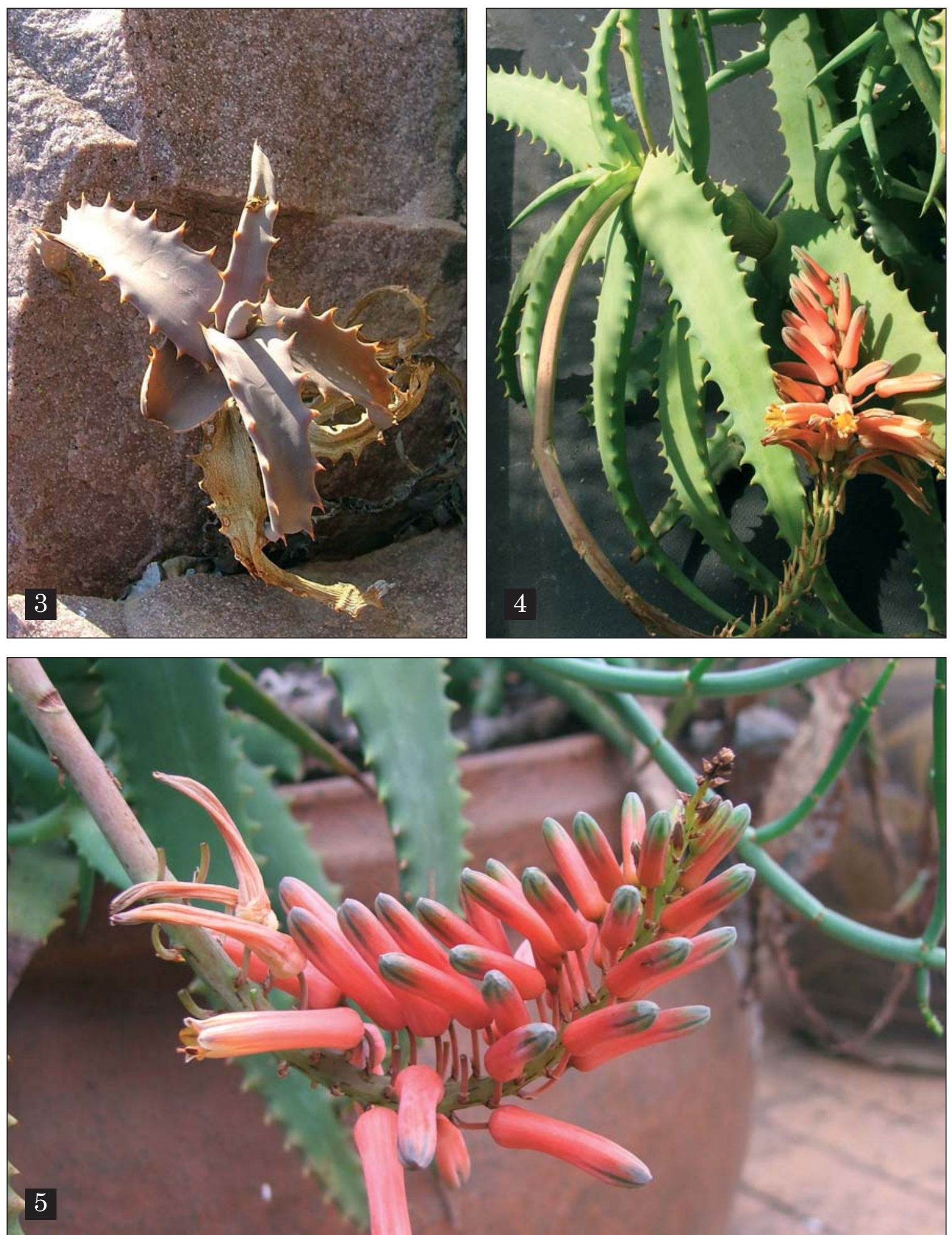

Figure 3. The original plant of $A$. huntleyana in its rock face habitat, collected in July 2004. The plant grows on east facing cliff faces. Figure 4. A. huntleyana in cultivation at Kirstenbosch. Figure 5. The subdense, subsecundly arranged raceme; note the green tipped buds. 

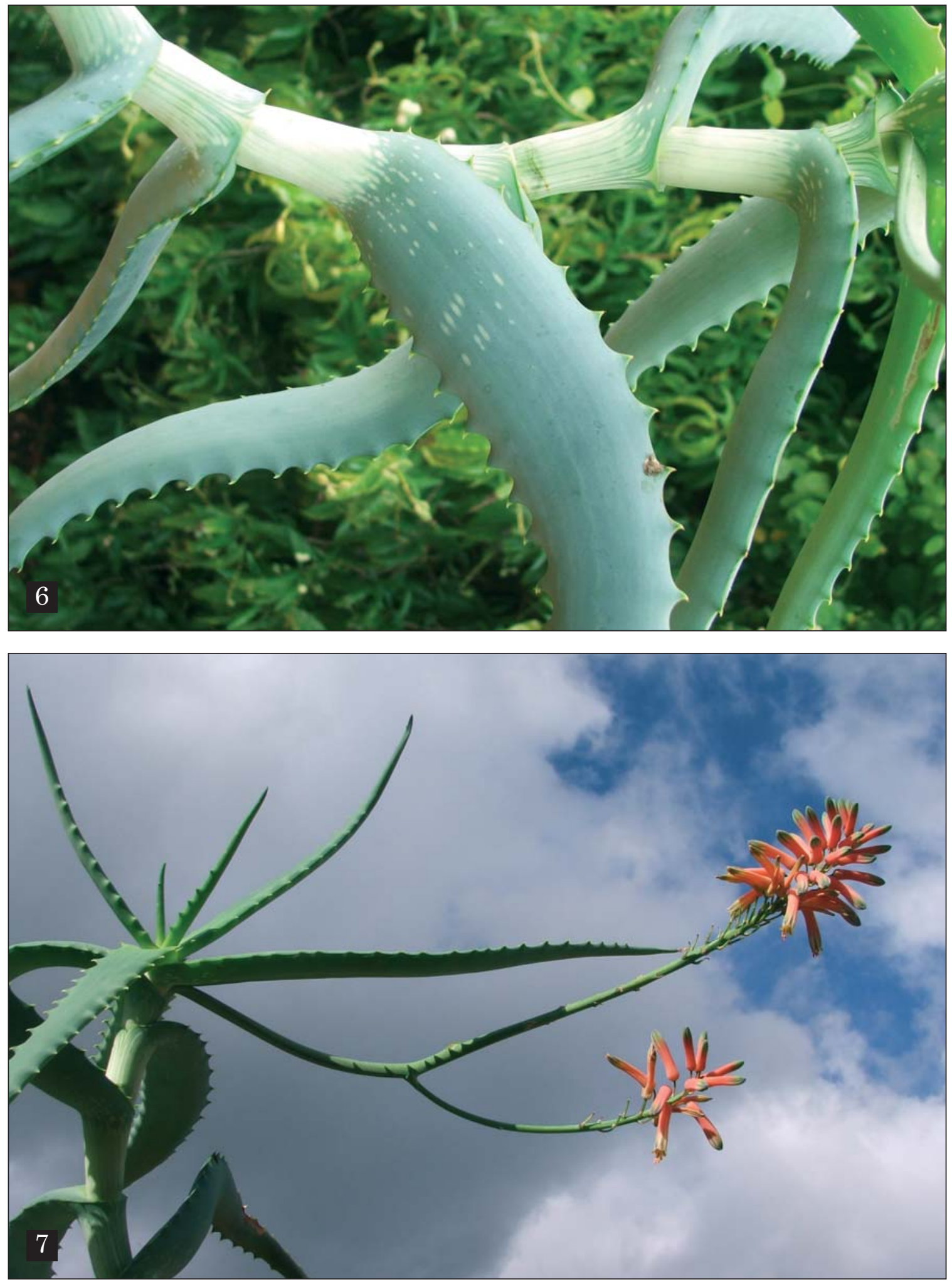

Figure 6. The stem of $A$. huntleyana. Figure 7. Plant showing the inflorescence and foliage. 
Table 1. Comparison of closely-related arborescent Aloe species (information mainly from Leach, 1974; Reynolds, 1966).

\begin{tabular}{|c|c|c|c|c|c|c|}
\hline & $\begin{array}{l}\text { A. catengiana } \\
\text { Reynolds }\end{array}$ & $\begin{array}{l}\text { A. gossweileri } \\
\text { Reynolds }\end{array}$ & A. huntleyana & $\begin{array}{l}\text { A. palmiformis } \\
\text { Baker }\end{array}$ & $\begin{array}{l}\text { A. scorpioides } \\
\text { Leach }\end{array}$ & $\begin{array}{l}\text { A. vallaris } \\
\text { Leach }\end{array}$ \\
\hline Distribution & \begin{tabular}{|l|} 
Catengue \\
Railway \\
Station, Angola \\
$400-500 \mathrm{~m}$
\end{tabular} & $\begin{array}{l}\text { East of Lobito, } \\
\text { Angola } 1,000 \mathrm{~m}\end{array}$ & $\begin{array}{l}\text { Omavanda, } \\
\text { Namibia } 1,600- \\
2,000 \mathrm{~m}\end{array}$ & \begin{tabular}{|l|} 
Lubango \\
Serra da Chella, \\
Angola 1,700- \\
$2,200 \mathrm{~m}$
\end{tabular} & $\begin{array}{l}\text { Lubango, Serra } \\
\text { da Chella and } \\
\text { Serra Neve, } \\
\text { Angola, } 900- \\
2,100 \mathrm{~m}\end{array}$ & \begin{tabular}{|l} 
escarpment \\
cliffs, Leba to \\
Tchivingueru, \\
SW Angola \\
$1,500-1,800 \mathrm{~m}$
\end{tabular} \\
\hline Geology & granite & granite & sandstone & sandstone & granite & sandstone \\
\hline Vegetation & $\begin{array}{l}\text { Mopane } \\
\text { savannah }\end{array}$ & gallery forest & $\begin{array}{l}\text { dry Combretum } \\
\text { savannah }\end{array}$ & $\begin{array}{l}\text { grassland \& } \\
\text { Miombo wood- } \\
\text { land }\end{array}$ & $\begin{array}{l}\text { Miombo } \\
\text { woodland \& } \\
\text { grassland }\end{array}$ & $\begin{array}{l}\text { afrotemperate } \\
\text { forest }\end{array}$ \\
\hline $\begin{array}{l}\text { Height } \\
\text { \& habit }\end{array}$ & $\begin{array}{l}\text { shrubby, thick- } \\
\text { ets } 1.5-3 \mathrm{~m} \text { in } \\
\text { diameter. } \\
\text { Branches } \\
\text { ascending, } \\
\text { deciduous below }\end{array}$ & \begin{tabular}{|l|}
$1-1.5 \mathrm{~m}$, erect, \\
branched from \\
the base, \\
deciduous below
\end{tabular} & $\begin{array}{l}\text { sprawling } \\
\text { branched, } \\
\text { shrubby, up to } \\
1 \text { m diameter } \\
\text { and } 50 \mathrm{~cm} \text { wide, } \\
\text { branches leafy }\end{array}$ & $\begin{array}{l}\text { erect, } 1-1.5 \mathrm{~m} \text {, } \\
\text { shrubby but } \\
\text { sparingly } \\
\text { branched, } \\
\text { deciduous below }\end{array}$ & $\begin{array}{l}\text { branched shrub } \\
\text { up to } 800 \mathrm{~mm} \text {, } \\
\text { deciduous below }\end{array}$ & $\begin{array}{l}\text { shrubby, } \\
\text { sprawling to } \\
\text { pendent, } \\
\text { branches leafy }\end{array}$ \\
\hline $\begin{array}{l}\text { Leaf colour } \\
\& \text { orientation }\end{array}$ & \begin{tabular}{|l|} 
pale yellowish, \\
grey-green, \\
numerous pale \\
green lenticular \\
spots, spreading \\
to deflexed near \\
base
\end{tabular} & $\begin{array}{l}\text { green, spread- } \\
\text { ing to slightly } \\
\text { recurved }\end{array}$ & $\begin{array}{l}\text { dull greyish } \\
\text { green, ascend- } \\
\text { ing, spreading }\end{array}$ & $\begin{array}{l}\text { dull green with } \\
\text { reddish tinge, } \\
\text { spotless, } \\
\text { spreading } \\
\text { recurved }\end{array}$ & \begin{tabular}{|l|} 
leaves yellowish \\
green, spreading- \\
recurved \\
$30 \times 3.5 \mathrm{~cm}$
\end{tabular} & $\begin{array}{l}\text { leaves tilted, } \\
\text { dull bluish to } \\
\text { greyish green }\end{array}$ \\
\hline $\begin{array}{l}\text { Leaf } \\
\text { margin }\end{array}$ & $\begin{array}{l}\text { sinuate-dentate } \\
\text { teeth } 3 \mathrm{~mm} \\
\text { long, } 8-10 \mathrm{~mm} \\
\text { distant }\end{array}$ & \begin{tabular}{|l|} 
sinuate-dentate, \\
teeth $3-4 \mathrm{~mm}$ \\
long, $15 \mathrm{~mm}$ \\
distant
\end{tabular} & \begin{tabular}{|l} 
sinuate-dentate, \\
teeth $3-5 \mathrm{~mm}$ \\
long, 8-12 $\mathrm{mm}$ \\
distant
\end{tabular} & \begin{tabular}{|l} 
sinuate-dentate, \\
teeth $4-5 \mathrm{~mm}$ \\
long, $10 \mathrm{~mm}$ \\
distant
\end{tabular} & $\begin{array}{l}\text { sinuate-dentate, } \\
\text { teeth } 2-3 \mathrm{~mm} \text {, } \\
10-15 \mathrm{~mm} \\
\text { distant }\end{array}$ & \begin{tabular}{|l|} 
dentate, teeth \\
$2-2.5 \mathrm{~mm}$ long, \\
$10-12 \mathrm{~mm}$ \\
distant
\end{tabular} \\
\hline Inflorescence & $\begin{array}{l}\text { branched } \\
\text { panicle, } 40 \mathrm{~cm} \\
\text { long, racemes } \\
\text { laxly flowered } \\
\text { cylindric- } \\
\text { acuminate, the } \\
\text { central } 160 \mathrm{~mm} \\
\text { long }\end{array}$ & \begin{tabular}{|l|} 
divaricately $6-8$ \\
branched, \\
pyramidal \\
panicle, \\
racemes $100-$ \\
150 mm long, \\
subsecundly \\
flowered
\end{tabular} & \begin{tabular}{|l|} 
simple to $3-$ \\
branched, $300-$ \\
$400 \mathrm{~mm}$ long, \\
racemes \\
subdensely \\
subsecundly \\
flowered, conical \\
trigonous, $80-$ \\
$150 \mathrm{~mm}$ long
\end{tabular} & $\begin{array}{l}\text { raceme, simple } \\
\text { or up to } 4- \\
\text { branched and } \\
40-50 \mathrm{~cm} \text { long, } \\
\text { racemes } \\
\text { cylindric } \\
\text { elongate } \\
10-20 \mathrm{~cm} \text { long }\end{array}$ & \begin{tabular}{|l|} 
simple or one- \\
branched, \\
racemes, arcuate \\
ascending, \\
raceme $11-25 \mathrm{~cm}$ \\
long, cylindric \\
acuminate or \\
long conical
\end{tabular} & $\begin{array}{l}\text { simple or one- } \\
\text { branched } \\
\text { racemes, } \\
\text { elongate, } \\
\text { cylindric } \\
\text { acuminate } \\
32-45 \text { cm long }\end{array}$ \\
\hline $\begin{array}{l}\text { Perianth } \\
\text { (mature) }\end{array}$ & $\begin{array}{l}\text { cylindric, } 28 \mathrm{~mm} \\
\text { long, slightly } \\
\text { decurved, } \\
\text { ovary } 6 \mathrm{~mm}, \\
\text { buds ascending } \\
\text { becoming } \\
\text { spreading when } \\
\text { mature }\end{array}$ & $\begin{array}{l}\text { cylindric- } \\
\text { trigonous, } 30 \\
\text { mm long, outer } \\
\text { segments free } \\
\text { for } 10-12 \mathrm{~mm} \text {, } \\
\text { flowers } \\
\text { drooping }\end{array}$ & $\begin{array}{l}\text { cylindric, } 28-29 \\
\text { mm long, } \\
\text { slightly curved, } \\
\text { outer segments } \\
\text { free for } 10 \mathrm{~mm}\end{array}$ & \begin{tabular}{|l|} 
cylindric- \\
trigonous, 30 \\
mm long, \\
segments free \\
for $10 \mathrm{~mm}$, buds \\
ascending, \\
flowers pendent, \\
ovary $6 \mathrm{~mm}$ \\
long
\end{tabular} & \begin{tabular}{|l|} 
cylindric- \\
trigonous, $24-$ \\
$28 \mathrm{~mm}$ long, \\
buds suberect, \\
becoming \\
drooping, ovary \\
pale green, $6 \mathrm{~mm}$ \\
long
\end{tabular} & $\begin{array}{l}\text { cylindric, } 20-25 \\
\text { mm long, } \\
\text { slightly curved, } \\
\text { outer segments } \\
\text { free for } 4.5-6 \\
\text { mm, flowers } \\
\text { vertically } \\
\text { presented, ovary } \\
5.5 \mathrm{~mm}\end{array}$ \\
\hline Flower colour & $\begin{array}{l}\text { rose-pink, } \\
\text { green-tipped }\end{array}$ & scarlet & reddish & rose-scarlet & scarlet & bright scarlet \\
\hline Pedicels & $10 \mathrm{~mm}$ & $10 \mathrm{~mm}$ & $8-10 \mathrm{~mm}$ & $13-15 \mathrm{~mm}$ & $8-10 \mathrm{~mm}$ & $4-4.5 \mathrm{~mm}$ \\
\hline Bracts & $\begin{array}{l}\text { ovate-acute, } \\
5 \times 3 \mathrm{~mm}\end{array}$ & $\begin{array}{l}\text { ovate-acute, } \\
3 \times 2 \mathrm{~mm}\end{array}$ & $\begin{array}{l}\text { ovate-acuminate, } \\
5 \times 3 \mathrm{~mm}\end{array}$ & $\begin{array}{l}\text { 2-3 mm long, } \\
\text { small }\end{array}$ & $\begin{array}{l}\text { linear-acuminate, } \\
6.5 \times 3.5 \mathrm{~mm}\end{array}$ & $\begin{array}{l}\text { ovate-acute, } \\
4.5 \times 2.5 \mathrm{~mm}\end{array}$ \\
\hline $\begin{array}{l}\text { Flowering } \\
\text { time }\end{array}$ & June, July & \begin{tabular}{|l|} 
June-July (mid- \\
winter)
\end{tabular} & April-June & April-June & May, June & April-June \\
\hline
\end{tabular}


wedged in crevices (Figure 3) and the rosette becomes pendent from a young age. The plants are rare and restricted to inaccessible cliffs. The plants are pollinated by sunbirds. The vegetation consists of savannah with plants such as Combretum apiculatum, C. zeyheri, Cyphostemma currorii, Entandrophragma spicatum, Kirkia acuminata and Mundulea sericea being prominent.

Associated cliff dwelling species include Cotyledon orbiculata, Cyphostemma currorii, Euphorbia subsalsa, E. monteiroi, Kalanchoe lanceolata and Sarcostemma viminale. Other non-succulent species include Ficus glumosa, F. ilicina and Petalidium coccineum. Omavanda is within the tropics, with hot summers and dry, warm winters without frost. Rainfall occurs mainly in summer with 300-500 mm per annum.

In vegetative features $A$. huntleyana closely resembles $A$. vallaris, a sister species from the western Angolan escarpment near Humpata (Leba Pass \& Tjivingueru). It is at once distinguished by its slightly larger size, internodes of $15-20 \mathrm{~mm}$ apart, larger flowers of $28 \mathrm{~mm}$ in length and dense shorter subdensely and subsecundly flowered racemes of $8-15 \mathrm{~cm}$. The raceme of $A$. vallaris is elongate $32-45 \mathrm{~cm}$ and the flowers 20-25 mm long, pendent when open. For differences between this closely related group, see Table 1. This group of aloes belongs to the arborescent group (Group 19 in Reynolds, 1966). In common most have a shrubby growth. The leaf sap of $A$. huntleyana is translucent but dries to a light yellowish brown colour.

We have pleasure in naming this species after Professor Brian Huntley for sponsoring one of us (E.v.J.) visiting Angola without which it would not have been possible to clearly place this species. The visit enabled him to study the close relatives in their native habitat. Professor Huntley has been the director of the National Botanical
Institute for a period of 20 years, during which this institute displayed tremendous growth under his leadership.

A. huntleyana is a worthwhile introduction to horticulture. It is best grown in dry bushveld gardens (Van Jaarsveld, 2010). It propagates readily from cuttings planted in a well-drained, sandy mixture and grows fairly fast. The plants thrive on steep embankments, in large hanging baskets or on windowsills. Outside its habitat, it is best grown under controlled conditions in containers in a greenhouse. Plants grown at Kirstenbosch are being increased by vegetative means and will be released and introduced through its annual plant sale and from the nursery at Kirstenbosch in future.

\section{Acknowledgements}

The authors are grateful to John Lavranos for the translation of the Latin Diagnosis and to colleagues Werner Voigt and Paul Emms. Duke Benadom is thanked for the clear photos of A. catengiana from his collection which enabled the authors to determine the new species.

\section{References}

LEACH, L.C. (1974). Notes on the Aloes of S. Tropical Africa with four new species and a new variety. J. S. Afr. Bot. 40: 101-122.

Reynolds, G.W. (1966). The aloes of Tropical Africa and Madagascar. The Trustees of the Aloes Book Fund, Box 234, Mbabane, Swaziland.

VAN JAARSvelD, E.J. (2008). The Kaokoveld (northern Namibia) reveals new plant treasures; new records, species, and the first record of Aloe catengiana. Aloe 45: 56-64.

VAN JAARSVELD, E.J. (2010). Waterwise Gardening in South Africa and Namibia. Struik, Cape Town. 